\title{
Miranda
}

Revue pluridisciplinaire du monde anglophone /

Multidisciplinary peer-reviewed journal on the English-

speaking world

$6 \mid 2012$

Marking the Land in North America

\section{Marks of Ambivalence: Thoughts on Perception and Inscription}

\section{Scott Slovic}

\section{OpenEdition}

\section{Journals}

\section{Electronic version}

URL: http://journals.openedition.org/miranda/2816

DOI: $10.4000 /$ miranda.2816

ISSN: 2108-6559

Publisher

Université Toulouse - Jean Jaurès

\section{Electronic reference}

Scott Slovic, "Marks of Ambivalence: Thoughts on Perception and Inscription", Miranda [Online], 6

2012, Online since 28 June 2012, connection on 16 February 2021. URL: http://

journals.openedition.org/miranda/2816 ; DOI: https://doi.org/10.4000/miranda.2816

This text was automatically generated on 16 February 2021.

\section{cc) (i) () $\Theta$}

Miranda is licensed under a Creative Commons Attribution-NonCommercial-NoDerivatives 4.0 International License. 


\title{
Marks of Ambivalence: Thoughts on Perception and Inscription
}

\author{
Scott Slovic
}

One of the especially compelling aspects of our topic for this special issue-marking the land in North America-is its very slipperiness, despite the apparent concreteness of the words. What could be more concrete than the word "mark," which in its most obvious meaning seems to imply placing a physical-most likely a visual-impact upon an object, perhaps literally to emblazon one's personal presence, or one's species' presence, upon the world? But the word "mark," of course, also implies-as in the phrase "mark my words"-to observe, to notice, to pay attention. So in a rephrasing of the philosophical conundrum "If a tree falls in the forest and no one is present to witness it, has a tree actually fallen?" we might ask, "Has a landscape actually been marked if nobody marks-or notices-the marking?" We might amplify this further by considering that the verb "to remark"-or to comment-adds a linguistic layer of meaning to the phrase "marking the land," implying the process of using language to speak or write about the physical world, which is what all of us working in the field of literature and environment do or think about on a daily basis. The words "land" and "North America" are similarly slippery and multifaceted, if we really think about them carefully-but I will leave the development of these complications to various contributors to this special issue, who have prepared articles on a wide range of topics, focusing on places explicitly located on the North American continent.

2 As a scholar in the field of ecocriticism who comes from the United States but spends a lot of time these days teaching and writing in other parts of the world, I would like to note that marking-or changing-the land is very much a global human phenomenon, that North Americans (in various ways) have tended to cause or contribute to "marking the land" in regions well beyond North America itself, and that there is a fascinating ambivalence inherent in the physical process of leaving a mark upon the world. My instinctive response to the phrase "marking the land" is to feel a kind of repulsion or guilt-to mark something is to mar it, to add a blemish to something once pure. I find myself thinking of the adage promulgated by the largest American conservation 
organization, the Sierra Club, which goes "Take nothing but photographs, leave nothing but footprints," but in remembering this I think of the time when I encountered this Sierra Club statement on a rusting sign in Chinese, along a remote hiking trail at the Wuyishan World Heritage Site in Fujian Province, China, in 2009-just beyond the sign advocating nothing but footprints was a large suspension bridge hanging over a small mountain river, a dramatic mark on the land created by the same people urging later visitors to leave no mark. I find myself thinking back as well to my visit to the guru of Japanese organic farming, Fukuoka Masanobu, at his jungle-like orchard near Matsuyama in 1994, when he showed us how he painted small poems in Japanese calligraphy on pieces of scrap metal and then simply tossed these off the path into the tropical forest-why make such human utterances and then secretly mark the land with them? This experience, in turn, brings to mind the world's largest work of literature, Chilean poet Raul Zurita's four-word, one-line poem which took eighteen years to plan and two or three days to bulldoze into a location in Chile's Atacama Desert unmarked on any map, some three hours by car from the small town of Antofogasta. The four-kilometer line of words, "ni pena ni miedo" (neither pain nor fear), is a massive mark on the land that is essentially invisible from the ground but has remained visible from overflying airplanes for more than a decade, an indictment of the brutalities of the Pinochet regime that echoes silently long after the disappearance of the dictator himself. American landscape writer William L. Fox has written a fascinating chapter remarking on Zurita's poetic landscape mark in the book All Along the Line, a work that studies the meaning of human-made lines (pipelines, art works, poems) inscribed upon places throughout the world. These are a few small examples of "marking the land" in regions of the world beyond North America-of course, the marking process, in all senses of the work "mark" (blemish, notice, comment), occur whenever and wherever human beings are present. Could one even define us as a "marking animal"?

Why bother to hold a conference and then produce a special journal issue to mark our human tendency to mark the land? What makes this process so interesting may be our intrinsic ambivalence about this very human tendency: our entire lives exert an impact, small or large, upon the planet, and yet we do not rest easily with this knowledge. One particularly poignant example of this curious human ambivalence is the case of the United States Department of Energy, which has gauged a five-kilometer tunnel through an obscure ridge called "Yucca Mountain" in the southern part of my state (Nevada), where the DOE has sought for some thirty years now to deposit all of our country's high-level nuclear waste-you would think that the DOE might want to hide this location (in China, for instance, the locations of nuclear waste repositories are secret), but instead artists have been commissioned to dream up elaborate "warning markers" (to use the DOE's language) that may someday be placed on top of this almost invisible finger of earth some 150 kilometers north of Las Vegas. Again, a strange ambivalencea yearning to sequester this shameful, dangerous waste in a remote, almost invisible desert tunnel and a desire to display its presence by way of artistic warning markers.

4 We have a particularly notable culture of marking the land in North America, but this is a topic of global interest and relevance. This special issue of Miranda seeks to mark and illuminate some of the American dimensions of the topic. 


\section{AUTHOR}

\section{SCOTT SLOVIC}

Professor

University of Nevada, Reno

slovic@unr.edu 